\title{
Interventricular Septal Aneurysm: an Exceptional cause of Sudden Death in Young Adult
} \author{
$\mathrm{S}^{3}$ and Hamdoun $\mathrm{M}^{1}$ \\ ${ }^{1}$ Department of Forensic Medicine-Charles Nicolle Hospital, Tunisia \\ ${ }^{2}$ Department of Cardiology-Military Hospital of Tunis, Tunisia \\ ${ }^{3}$ Department of Histology - Charles Nicolle Hospital, Tunis, Tunisia
}

Naceur Yomn*1, Houissa $\mathrm{K}^{2}$, Banaser $\mathrm{A}^{1}$, Gharbaoui $\mathrm{M}^{1}$, Bekir $\mathbf{0}^{1}$, Daly $\mathrm{Y}^{1}$, Ben Khelil $\mathrm{M}^{1}$, Allouche $\mathrm{M}^{1}$, Rammah

Submission: March 01, 2018; Published: March 22, 2018

*Corresponding author: Naceur Yomn MD, Department of Forensic Medicine-Charles Nicolle Hospital-Tunis, Tunisia, Email: naceuryomn@gmail.co

\begin{abstract}
Interventricular septal aneurysms are extremely rare congenital or acquired cardiac diseases associated with some fatal complications. We reported the case of an apparently healthy man of 38 years of age who suddenly died. Autopsy found a large membranous septal aneurysm bulging in the left outflow tract without any septal defect or other structural heart disease. We presume that conduction disorder or left outflow obstruction could be the cause of this sudden death.
\end{abstract}

Keywords : Interventricular Septal Aneurysm; Sudden Cardiac Death; Autopsy

\section{Introduction}

Interventricular septal aneurysm (VSA) is a rare cardiac anomaly mostly associated with a ventricular septal defect or other congenital heart diseases [1,2]. Isolated VSA is more rarely reported, without any data about its real incidence. Patients are generally asymptomatic and as result VSAs are incidentally discovered during cardiac imaging tests or autopsy. Although thromboembolism, ventricular outflow tract obstruction and cardiac rhythm disturbance [3-5] are described complications of VSA, establishing a causal relationship between isolated VSA and unexpected death is still to debate.

\section{Case report}

A 38 years old man, apparently healthy, suddenly died. He had no relevant medical history and no prior symptoms were noticed. There was no family history of sudden cardiac death or any known congenital disease. Death occurs at his own home when he was trying to hang a painting in the wall. At autopsy, the heart weighed $390 \mathrm{~g}$ without any marked hypertrophy or dilatation of both ventricles. A large aneurysm of the membranous septum (55 x $35 \times 20 \mathrm{~mm}$ ) was found with irregular cavity borders (Figures 1 \& 2). The aneurysm was extending into the left ventricular outflow tract inferior to the aortic valve without any evidence of thrombus formation or dissection. There was no associated ventricular septal defect. Coronary arteries were patent and healthy and no sign of myocardial infarction were recorded. There was not any valvular or great arteries abnormalities.

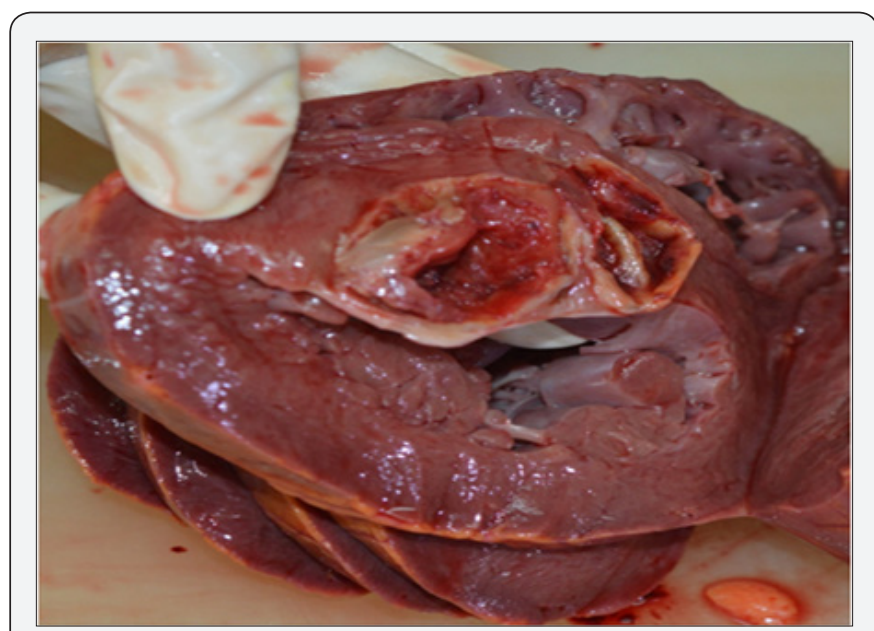

Figure 1: Short axis section through the interventricular septal aneurysm.

RV: Right Ventricle ; VSA: Interventricular Septal Aneurysm ; LV: Left Ventricle.

Toxicological and mycobacterial examination were negative. Histological examination showed that the two aneurysm walls present a similar architecture: sclera hyaline wall including 
foamy histiocytes and siderophages with abundant calcium deposit. Adjacent heart tissue presents focal fibrosis with hypertrophic aspect of cardiomyocytes. There was no obvious abnormality of the conductive tissue.

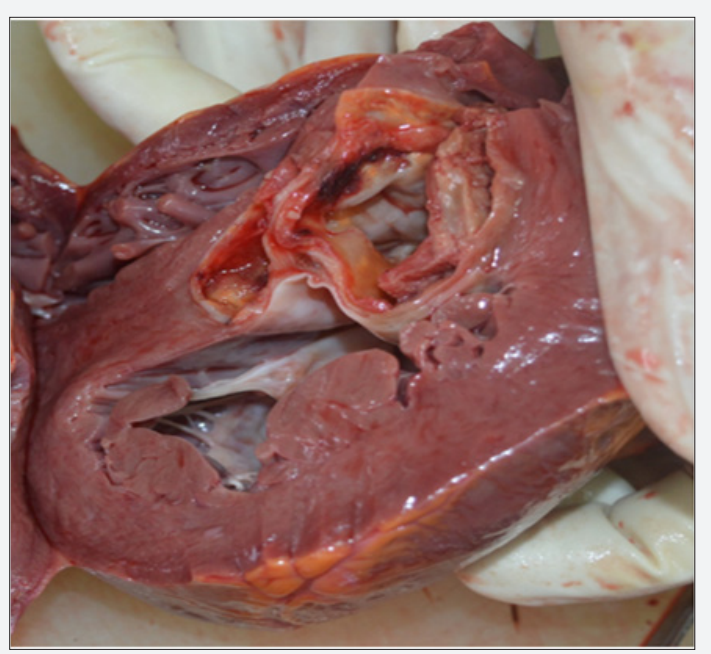

Figure 2: Short axis section through the basal interventricular septum showing the aneurysm bulging in the left ventricular outflow tract.

\section{Discussion}

Isolated aneurysms of the membranous ventricular septum are extremely rare with very few case reports in the literature. Therapeutic management is often problematic when VSA is incidentally diagnosed in asymptomatic patient, and when discovered on autopsy the dilemma is how can it explain an "unexplained" death. Natural course of this disease remains unpredictable; even if in some cases favorable outcomes are reported without any therapeutic intervention $[6,7]$ serious and sometimes fatal complications may occurs [8,9]. Cardiac rhythm and conduction disorders in patient with VSA were described in several papers $[10,11]$. Complete atrioventricular block, left or most frequently right bundle block were reported $[4,5,9]$. These complications could be explained by the compression of the conduction pathways by fibrotic tissue around the aneurysm [12]. Ventricular tachycardia was also reported [13,14] with good response to surgical or catheter ablation in treated cases. Ventricular outflow obstruction concerns mostly the right tract [15-17], exceptionally, the VSA can bulge into the left ventricular outflow tract leading to a functional aortic stenosis [8,18-20]. Bacterial endocarditis and thromboembolic accidents were also reported as complications of VSA [21-23]. The VSA described in this case was particular by its bulging in the left outflow tract with a relative large size and without any other structural heart abnormalities. These facts let the authors presume that the sudden death may be the consequence of an obstruction of the left ventricular outflow tract by the aneurysm, even if this hypothesis seems unlikely given that the patient has been completely asymptomatic for 38 years. The second mechanism which could explain this sudden death is rhythm or conduction disturbance, but it would remain only speculations due to the absence of histological proof of conductive pathways damage.

\section{Conclusion}

Ventricular septal aneurysm is a rare cardiac disease not devoid of fatal complications. Rhythm and conduction disorders are the main cause of sudden cardiac death associated with VSA, medical history records and appropriate histological examination are mandatory to establish a causality relationship between VSA and sudden cardiac death.

\section{References}

1. Cabrera A, Idígoras G, Sarrionandia MJ, Peña P, Lizárraga M, et al. (1992) The usefulness of two-dimensional echocardiography in the diagnosis of an interventricular aneurysm. Rev Esp Cardiol 45(2): 111-116.

2. Lazarev SM, Volkov AB (1989) Cineangiographic diagnosis of an aneurysm of the membranous part of the heart septum. Vestn Rentgenol Radiol, p. 50-54.

3. Loukas M, Tubbs RS, Louis RG, Curry B (2006) Pseudoaneurysm of the membranous septum, case report and review of the literature. Surg Radiol Anat 28(6): 564-568.

4. Thery C, Lekieffre J, Dupuis C (1975) Atrioventricular block secondary to a congenital aneurysm of the membranous septum. Histological examination of conduction system. Br Heart J 37(10): 1097-1100.

5. Márquez FJG, Vargas Machuca MG, Cano BP, Bustos AR, Morgado JM, et al. (2016) Aneurysmal Membranous Septum As an Exceptional Cause of Paroxysmal Atrioventricular Block. Rev Esp Cardiol 69: 226-228.

6. Naidu A, Ricketts M, Goela A, Shoemaker G, Li S (2012) Incidental Discovery of a Membranous Ventricular Septal Aneurysm in Two Dissimilar Patients. Case Rep Cardiol.

7. Deaconu A, Iancovici S, Wellnhofer E, Berger A, Gebker R, et al. (2015) Interventricular septum aneurysm: Two differently managed cases and association with bicuspid aortic valve. Int J Cardiol 201: 438-440.

8. Kusz B, Mizia M, Wróbel W, Mizia Stec K (2016) Huge interventricular septal aneurysm diagnosed in vivo in an adult. Pol Arch Med Wewn 126(10): 789-790.

9. Sarubbi B, Gerlis LM, Ho SY, Somerville J (1999) Sudden death in an adult with a small ventricular septal defect and an aneurysmal membranous septum. Cardiol Young 9(1): 99-103.

10. Kaplan M, Murat Demirtaş M, Sayrak H, Cimen S, Dagsali S, et al. (2000) An anatomopathologic study of membranous septum aneurysms and significance of their surgical treatment. Cardiovasc Surg Lond Engl 8(7): 561-566.

11. Heggtveit HA (1964) Congenital aneurysm of the membranous septum associated with bundle branch block. Am J Cardiol 14(1): 112-117.

12. Kurosawa H, Becker AE (1989) The conduction bundle at the atrioventricular junction An anatomical study. Eur Assoc Cardio Thorac Surg 3(4): 283-287.

13. Graffigna A, Minzioni G, Ressia L, Vigano M (1994) Surgical ablation of ventricular tachycardia secondary to congenital ventricular septal aneurysm. Ann Thorac Surg 57(4): 921-924.

14. Carbucicchio C, Al Mohani G, Casella M, Pizzamiglio F, Catto V, et al. (2015) Uncommon ventricular tachycardia originating from an interventricular septal aneurism: Mapping and ablation guided by real-time image integration. Int J Cardiol 185: 103-105.

15. Güneş Y, Erbaş C, Okçün B, Babalik E (2004) A case of ventricular septal aneurysm producing right ventricular outflow obstruction in an adult patient. Anadolu Kardiyol Derg 4(4): 346-347. 
16. Chen SY, Chan KL, Beauchesne LM (2011) Right ventricular outflow tract obstruction secondary to a membranous ventricular septal aneurysm. Eur J Echocardiogr J 12(11): pp: 886.

17. Love BA, Parness IA, Fuster V (2009) Membranous septal aneurysm causing right ventricular outflow tract obstruction. Clin Cardiol 32(12): 87

18. Barron JV, Sahn DJ, Valdes Cruz LM, Grenadier E, Allen HD, et al. (1982) Two-dimensional echocardiographic features of ventricular septal aneurysm paradoxically bulging into the left ventricular outflow tract Am Heart J 104(1): 156-158.

19. Frary G, Hasselman T, Patel P (2012) Atypical left ventricular outflow tract aneurysm diagnosed by three-dimensional echocardiography. Cardiol Young 22(4): 478-480.
20. Farahani MM (2010) Mass-Like Aneurysm of the Left Ventricular Outflow Tract. Tex Heart Inst J 37(5): 610-611.

21. Varghese PJ, Izukawa T, Celermajer J, Simon A, Rowe RD (1969) Aneurysm of the membranous ventricular septum. A method of spontaneous closure of small ventricular septal defect. Am J Cardiol 24(4): 531-536.

22. Vidne BA, Chiariello L, Wagner H, Subramanian S (1976) Aneurysm of the membranous ventricular septum. Surgical consideration and experience in 29 cases. J Thorac Cardiovasc Surg 71(3): 402-409.

23. Warembourg H, Bertrand ME, Dupuis C, Théry C, Ginestet A, et al. (1975) Aneurysms of the membranous septum. Apropos of 4 cases. Arch Mal Coeur Vaiss 68: 1051-1060.

\section{Your next submission with Juniper Publishers} will reach you the below assets

- Quality Editorial service

- Swift Peer Review

- Reprints availability

- E-prints Service

- Manuscript Podcast for convenient understanding

- Global attainment for your research

- Manuscript accessibility in different formats

( Pdf, E-pub, Full Text, Audio)

- Unceasing customer service

Track the below URL for one-step submission https://juniperpublishers.com/online-submission.php 